\title{
Editorial
}

\section{Possible health effects of working with VDUs}

The possibility that working with visual display units may cause adverse effects on health and wellbeing has been intensively studied and debated in several countries. I will attempt to outline the present state of the art concerning this issue.

Because of the widespread use of VDUs rare conditions may appear (in individuals and also in clusters) without any causal relation necessarily being present. Thus the presence-for example, from case reports-of a health effect in a VDU worker is not the issue per se-some indication of association and causality is also required (from comparisons with an appropriate referent group, from intervention studies, from knowledge about known causal factors present where VDUs are used, or a combination of these.

A problem when evaluating some issues is that the information on which the scientific and public debate is based may not have been published in peer review form. Several reviews on the topic do exist; an extensive bibliography is to be found in the WHO publication: "Visual display terminals and workers' health."

\section{What constitutes "exposure" when working with VDUs?}

There has been a shift in the scientific emphasis from "VDU exposure" to "working with VDUs" as motivated by, for example, the considerable difference found in the prevalence of discomfort between workers with different VDU work tasks. Basically, the designation "VDU work" as used in epidemiological studies includes several factors, both those inherently due to the equipment (electromagnetic phenomena, flickering screens, or software design) and those correlated with varying degrees with VDU use (problematic office lighting, physical inactivity, or software function training). Thus some problems may be restated as: "investigation of health effects of factors commonly found in VDU work."

Accordingly, many possible causal factors of adverse health effects exist in VDU work. Some will be considered here including those associated with office work where VDUs based on cathode ray tubes (CRT, common television technology) are used, and those centred on the workplace/work task (excluding many social organisational concerns).

\section{Effects on eyes and vision}

There are several different measures of effects on the eyes and on vision including changes in reading performance, transient effects such as discomfort and changes in ocular function, and, finally, the possibility of permanent change or injury to the visual system.

Experimental studies of readability and legibility have generally disclosed poorer performance (reading speed, for example) with VDU displayed text on paper, ${ }^{23}$ apparently due to combinations of various display and environmental parameters ("display quality"). This is in concordance with the almost ubiquitous finding of an increased frequency of eye discomfort reported among VDU operators compared with office workers who do not use VDUs. ${ }^{145}$ This is attributed to a combination of VDU and other office visual ergonomic parameters, ${ }^{6-9}$ one example being excessive luminance contrasts between dark screens and brighter manuscripts.

The prevalence of eye discomfort and visual fatigue varies considerably between operators performing different VDU jobs-with data entry as one "high risk" group. ${ }^{10}$ In a paper aptly named "the magic of control groups ..." it is pointed out that the choice of referent group will strongly influence the outcome of the comparison between the groups: there may be circumstances where the "control" group is equally (or more) exposed to poor visual ergonomic conditions than the VDU work group." Under "normal" office conditions, however, the introduction of VDUs has often tended to aggravate visual ergonomic problems.

There has been only limited success in determining measurable physiological correlates of eye discomfort. $^{112-15}$ Efforts have largely been directed towards various oculomuscular functions, such as accommodation. Concern is presently limited to transient, reversible conditions such as discomfort, since investigations have failed to find evidence of any lasting damage. ${ }^{\prime}$ There is, however, a lack of data concerning 
possible long term consequences of prolonged occular discomfort.

\section{Musculoskeletal effects}

There is a high prevalence of musculoskeletal problems among office workers, notably in the neckshoulder region. Several studies have suggested that this prevalence is increased in some VDU work compared with non-VDU office work. ${ }^{15 a-18}$

Muscle problems can be considered as a consequence of a high degree of repetitive movement, posture, or physical activity/inactivity. Some relevant (presumed) causative factors in VDU work are equipment (work station configuration, visual ergonomics, and keyboard construction), type of work and organisation (work task, duration, breaks, and flexibility), as well as individual factors (anthropometry, vision, and control).'

As exemplified by the RSI (repetitive strain injury) debate in Australia, there is uncertainty as to the delineation between discomfort and injury. ${ }^{19}$ The WHO working group pointed out that while there is a possibility for "injury from repeated stress to the musculoskeletal system," discomfort does not "inevitably lead to injury [and is not] necessarily a sign of injury.",

\section{Skin problems}

In Norway and Sweden considerable interest has been focused on the possibility of excess occurrences of skin problems among VDU operators. Reports on this are somewhat limited and the summary below relies partly on unpublished reports.

Some epidemiological studies have indicated an excess of skin reactions among female VDU operators, predominantly manifestations of common skin problems, such as acne, rosacea, and seborrhoic eczema. ${ }^{4021}$ The mechanisms behind this association have not been identified, although factors such as low humidity or stress, or both, have been suggested. Owing to the failure to find an association between electrostatic fields from VDUs and these skin problems, such fields are not thought to have a causal influence. ${ }^{2022}$

Cases of a somewhat different symptomatology (transient rash, tingling) have, however, also been described. ${ }^{23}{ }^{24}$ Causal factors for these much less common conditions remain unknown; both physical and psychological factors have been suggested.

\section{Pregnancy outcome}

The question as to whether work with VDUs may affect pregnancy outcome has been investigated dur- ing the past decade after the reporting of groups of pregnant VDU operators with an unusually high frequency of spontaneous abortion or a high occurrence of serious malformations. These clusters are explicable by chance, given the large VDU work population without assuming the involvement of any specific VDU factor(s). ${ }^{25}$

An alternative explanation of these clusters would depend on the identification of a plausible causal factor in VDU work from animal studies or from human observations, or both. Attention has lately been focused on either stress or magnetic fields from VDUs. Stress and worry have been indicated but not established as factors leading to spontaneous abortion. ${ }^{26}$ As for magnetic fields, some unpublished studies have suggested a teratogenic or teratotoxic effect, or both, whereas other (unpublished) studies have failed to indicate such effects. ${ }^{27-30}$ An ad hoc committee of the Swedish Medical Association drew the following conclusions: "Cell biological and cytogenetic investigations have not been able to show convincing effects of EMF, nor been able to generate plausible models for possible effect mechanisms concerning teratogenic or carcinogenic effects. ... Studies of embryonic development have not been able to show specific, unequivocal effects of EMF. The results are partly contradictory and do not show a convincing reproducibility. Therefore they cannot be used for conclusions concerning possible effects of VDU exposure on pregnancy outcome in people."31 My translation from Swedish, EMF = electromagnetic fields.

Several epidemiological studies on (primarily) spontaneous abortion and serious malformations in pregnancies of VDU operators have also been performed. In general, and specifically in the methodologically reliable studies, no significant difference attributable to VDU work has been established ${ }^{32-35}$ (and W Butler, American Statistical Association Meeting, Chicago, 1986) (see also reviews ${ }^{136}$ ). An exception to this is the recently published "Kaiser Permanente study" from northern California, where a significant excess of spontanous abortion was found among clerical workers with long VDU work times compared with those without VDU work. In other occupational groups, however, there was a significant decrease among VDU workers with moderate duration compared with those who did not use VDUs. The authors made no definite conclusions as to causal factors from their study but emphasised the possibility of work conditions such as stress or ergonomic conditions, or both. ${ }^{37}$

The main conclusion to be made is that there is no evidence for an effect of VDU work on pregnancy outcome, implying that either there is in reality no such effect or that if there is the risk increase is so minor as to avoid "detection" by the studies so far 
performed. Based on some findings ${ }^{33}$ and deliberations, ${ }^{126}$ however, some concern appears warranted regarding certain work conditions such as stress and miscarriages.

\section{Some other effects}

In the debate and in (primarily) unpublished reports, some other health problems appearing among VDU workers have been briefly mentioned:

Photosensitive epileptic seizures have been observed in connection with television viewing. For VDU work the effect appears possible but unlikely, due both to some technical differences and to the presumed avoidance of displays by sensitive people. ${ }^{138} 39$

In a questionnaire study "chest pain" (termed "angina" in the report) was reported more commonly by VDU operators and workers with lower job control. ${ }^{40}$ This finding is devaluated by a low response rate $(35 \%)$ and by the ambiguous meaning of the term chest pain, which apart from cardiac causes could also be due to musculoskeletal or gastroinestinal conditions. ${ }^{41}$

Other suggested effects have been that of struma, breast cancer, and immunological deficiencies (all from unpublished sources). (As for struma, no difference between VDU operators and referents in the percentage who had had medical treatment/examination for struma was found in one investigation. ${ }^{4}$ ) The (general) lack of current supporting evidence gives a low present credibility to these suggestions.

\section{Stress factors and stress mediated effects}

The WHO working group pointed out that "little consistent evidence of abnormal levels of stress related disorders" was found among VDU workers but that "considerable evidence that stress factors associated with that work may create health problems" existed.
Further research is warranted and efforts to improve working conditions in these respects is urged (see the WHO review for further discussion.')

Several stress factors occur in some VDU work, some, such as system reliability and response delays, ${ }^{4243}$ software design, ${ }^{44-46}$ and monitoring ${ }^{40}$ being machine system orientated whereas others are more "organisation orientated"-for example, job task changes, manner of VDU system introduction, education, and training. ${ }^{47}$ Special interest is often directed towards jobs with quantitative overload, qualitative underload, and lack of personal control and social support-a notable example being routine data entry work. ${ }^{48} 49$

Stress conditions have already been referred to in relation to several effects considered above: musculoskeletal problems, skin problems, and the discussion on miscarriages. For the first two, there exist both general (as to physiological mechanisms) and VDU specific indications of stress as a marker for or as a link in a causal chain, whereas the situation is less clear as regards risks of miscarriage.

\section{Summary}

A summary of the effects presented here is given in the table. The designation "factor present" implies that there is knowledge (from human or animal studies, or both) of a specific factor(s) present in VDU work which may be part of a causal link. The designation "summary statement" gives my conclusions of the relation between VDU work and the various effects; the "state of the art."

Suggestions for "additional" health effects have also appeared but so far generally without supporting or suggesting evidence.

U BERGQVIST

Department of Neuromedicine,

National Institute of Occupational Health,

S-171 84 Solna, Sweden.

Relation between VDU work and various health effects

\begin{tabular}{|c|c|c|c|c|c|c|}
\hline \multirow[b]{2}{*}{ Effect } & \multicolumn{3}{|c|}{$\begin{array}{l}\text { Is there an association between VDU work and the } \\
\text { effect? }\end{array}$} & \multicolumn{3}{|c|}{ If so, emphasis of causal factors to be found in: } \\
\hline & $\begin{array}{l}\text { Factor } \\
\text { present }\end{array}$ & $\begin{array}{l}\text { Epidemiological } \\
\text { evidence }\end{array}$ & $\begin{array}{l}\text { Summary } \\
\text { statement }\end{array}$ & $\begin{array}{l}\text { VDU } \\
\text { system }\end{array}$ & $\begin{array}{l}\text { Environment, } \\
\text { work station }\end{array}$ & $\begin{array}{l}\text { Work task and } \\
\text { organisation }\end{array}$ \\
\hline $\begin{array}{l}\text { Eye discomfort } \\
\text { Eye injury } \\
\text { Muscle problems } \\
\text { (Stress reactions } \\
\text { Skin problems } \\
\text { Pregnancy outcomes }\end{array}$ & $\begin{array}{l}\text { Yes } \\
\text { No } \\
\text { Yes } \\
\text { Yes } \\
? \\
\text { No?* }\end{array}$ & $\begin{array}{l}\text { Yes } \\
\text { No† } \\
\text { Yes?‡ } \\
\text { Varies } \\
\text { Yes? } \\
\text { No?* }\end{array}$ & $\begin{array}{l}\text { Yes } \\
\text { No† } \\
\text { Yes/variesł } \\
\text { Varies } \\
\text { Yes??\| } \\
\text { No* }\end{array}$ & $\begin{array}{l}\mathbf{x x x} \\
\mathbf{x} \\
\mathbf{x x} \\
?\end{array}$ & $\begin{array}{l}\mathbf{x x} \\
\mathbf{x x x} \\
\mathbf{x} ?\end{array}$ & $\begin{array}{l}\mathbf{x x} \\
\mathbf{x x x} \\
\mathbf{x x x}) \\
\mathbf{x} ? \\
?\end{array}$ \\
\hline
\end{tabular}

* Some credibility of an association with stress and worry.

† Long term consequencies of discomfort not investigated.

†Primarily neck-shoulder region.

\$Predominantly dependent on factors not specifically associated with VDUs.

i|Tentative yes as to association, scant information as to a causal link. 


\section{Editor's note}

The recent House of Lords' European Communities Committee has drawn the same conclusions as this editorial. The committee has concluded, therefore, that the proposal to legislate for minimum health and safety standards for users of VDUs throughout the Community should not be pursued. ${ }^{50}$ The proposed EC legislation would require employers to evaluate the health risks of working with VDUs and to take appropriate remedial action; it would impose minimum standards for equipment such as the display screen, desk, chair, and lighting and for environmental conditions such as noise and humidity; VDU operators would be given the opportunity to have tests of visual acuity and employers would have to pay for special glasses if these were found to be required; and VDU operators would be required to receive training and information about the possible risks to health.

It would seem to us that good employers should be undertaking these tasks as part of their general concern to ensure that the health of their employees is not adversely affected by their work. The principal objection of the House of Lords Committee to the proposal seems to lie in the fact that it would take the form of binding law and they consider that voluntary codes of practice would be more appropriate. We would take the view that the health and safety of those at work may be too important an issue to be left to voluntary effort and that some degree of coercion may still be necessary, even in these so called enlightened times, to ensure that all employers conform to the best and safest practices.

\section{References}

1 World Health Organisation. Visual display terminals and workers health. Geneva: WHO, 1987. (Offset publication No 99.)

2 Gould JD, Grischkowsky N. Doing the same work with hard copy and with cathode-ray tube (CRT) computer terminals. Human Factors 1984;26:323-37.

3 Kruk RS, Muter P. Reading of continuous text on video screens. Human Factors 1984;26:339-45.

4 Knave BG, Wibom RI, Voss M, Hedström LD, Bergqvist UOV. Work with video display terminals among office employees. I. Subjective symptoms and discomforts. Scand J Work Environ Health 1985;11:457-66.

5 Rossignol AM, Morse EP, Summers VM, Pagnotto LD. Video display terminal use and reported health symptoms among Massachusetts clerical workers. J Occup Med 1987;29:112-8.

6 Delvolvé N, Queinnec Y. Operator's activities at CRT terminals: a behavioural approach. Ergonomics 1983;26:329-40.

7 Fellman T, Bräuninger U, Gierer R, Grandjean E. An ergonomic evaluation of VDTs. Behaviour Information Technology 1982; 1:69-80.

8 Knave BG, Wibom RI, Bergqvist UOV, Carlsson LLW, Levin MIB, Nylén PR. Work with video display terminals among office employees. II. Physical exposure factors. Scand J Work Environ Health 1985;11:467-74.

9 Meyer JJ. Lérgonomie de la vision face aux problémes des écrans de visualisation. Schweiz Rundsch Med Prax 1983;72:139-46.
10 van der Heiden GH, Bräuninger U, Grandjean E. Ergonomic studies on computer aided design. In: Grandjean E, ed. Ergonomics and health in modern offices. London: Taylor \& Francis, 1984:119-28.

11 Läubli T, Grandjean E. The magic of control groups in VDT field studies. In: Grandjean E, ed. Ergonomics and health in modern offices. London: Taylor \& Francis, 1984:105-12.

12 Tanahashi M, Miyao M, Sakakibara $\mathrm{H}$, et al. The effect of VDT work on the fluctuations of accommodation. Industrial Health 1986;24:173-89.

13 Iwasaki T, Kurimoto S. Objective evaluation of eye strain using measurements of accommodative oscillation. Ergonomics 1987;30:581-7.

14 Harima M, Horiguchi S, Karai I, et al. Pupillary changes due to work using visual display terminals. Int Arch Occup Environ Health 1988;60:303-6.

15 Gobba FM, Broglia A, Sarti R, Luberto F, Cavalleri A. Visual fatigue in video display terminal operators: objective measure and relation to environmental conditions. Int Arch Occup o Environ Health 1988;60:81-7.

15a Arndt R. Working posture and musculoskeletal problems of video display terminal operators-review and reappraisal. Am Ind Hyg Assoc 1983;44:437-46.

16 Hagberg M, Sundelin G. Discomfort and load on the upper trapezius muscle when operating a wordprocessor. Ergonomics 1986;29:1637-45.

17 Hagberg M, Wegman DH. Prevalence rates and odds ratios of shoulder-neck diseases in different occupational groups. $\mathrm{Br} J$ Ind Med 1987;44:602-10.

18 Hünting W, Läubli T, Grandjean E. Postural and visual loads at VDT workplaces I. Constrained postures. Ergonomics 1981; 24:917-31.

19 Commonwealth Department of Health. Repetition strain injury in the Australian Public Service. (Task force report.) Canberra: Australian Government Publishing Service, 1985.

20 Lidén C, Wahlberg J. Work at video display terminals. An epidemiological health investigation of office employees. $\mathrm{V}$. Dermatological examination. Scand $J$ Work Environ Health 1985;11:489-93.

21 Svensson E, Svensson J. Långvarigt bildskärmsarbete gav lindrig hudbesvär-tendens till ökning vintertid. (Long term VDT work resulted in slight skin problems-a tendency for increase during winter. In Swedish.). Läkartidningen 1987;84:1843-5.

22 Wahlberg JE, Liden C. Is the skin affected by work at visual display terminals? Dermatol Clinics 1988;6:81-5.

23 Nilsen A. Facial rash in visual display unit operators. Contact Dermatitis 1982;8:25-8

24 Fisher AA. "Terminal" dermatitis due to computers (visual display units). Cutis 1986;37:153-4.

25 Bergqvist UOV. Video display terminals and health. Scand J Work Environ Health 1984;10suppl 2:1-87.

26 MacKay C. The alleged reproductive hazards of VDUs. Work \& Stress 1987;1:49-57.

27 Sandström M, Hansson-Mild K, Lövstrup S. Effects of weak pulsed magnetic fields on chick embryogenesis. In: Knave B, Widebäck PG, eds. Work with display units 86. Amsterdam: Elsevier, 1987:135-40.

28 Stuchly MA, Ruddick J, Lecuyer DW, Robinson K, Tan K, Wong J. Teratological study of rats exposed to magnetic fields. In: $\omega$ Project resumés. Biological effects from electric and magnetic $\underset{-}{0}$ fields, air ions and ion currents associated with high voltage transmission lines. Contractors review. Washington DC: US Department of Energy, 1987.

29 Tribukait B, Cekan E, Paulsson LE. Effects of pulsed magnetic : fields on embryonic development in mice. In: Knave B, Widebäck PG, eds. Work with display units 86. Amsterdam: Elsevier, 1987:129-34.

30 Frölen H, Svedenstål BM, Bierke P, Fellner-Feldegg H. Upprepade studier av verkan av pulserande magnetfält pả fosterutveckling hos mus. (Repeated studies of the effect of pulsed magnetic fields on the embryonic development in mice. In 
Swedish.) (Final report, SSI 346.) Solna: National Institute of Radiation Protection, 1987.

31 Läkarsällskapets Ad hoc kommitté för bedömning av eventuella samband mellan exponering för magnetfält och kromosomskador, respektive cancer eller graviditetsstörningar. (The Swedish Medical Association's ad hoc committee for evaluation of possible causal relations between exposure to magnetic fields and chromosomal damage, cancer or reproductive effects. In Swedish.) Stockholm: Svenska Läkarsällskapet, 1988.

32 Kurppa K, Holmberg PC, Rantala K, Nurminen T, Saxén L. Birth defects and exposure to video display terminals during pregnancy. Scand J Work Environ Health 1985;11:353-6.

33 Ericson A, Källén B. An epidemiological study of work with video screens and pregnancy outcome: II. A case-control study. Am J Ind Med 1986;9:459-75.

34 McDonald AD, McDonald JC, Armstrong B, Cherry N, Nolin $\mathrm{AD}$, Robert $\mathrm{D}$. Work with display units in pregnancy. Br $J$ Ind Med 1988;45:509-15.

35 Westerholm P, Ericson A. Pregnancy outcome and VDU-work in a cohort of insurance clerks. In: Knave B, Widebäck PG, eds. Work with display units 86. Amsterdam: Elsevier, 1987:104-10.

36 Bergqvist UOV. Pregnancy and VDT work-an evaluation of the state of the art. In: Knave B, Widebäck PG, eds. Work with display units 86. Amsterdam: Elsevier, 1987:87-93.

37 Goldhaber MK, Polen MR, Hiatt RA. The risk of miscarriage and birth defects among women who use visual display terminals during pregnancy. Am J Ind Med 1988;13:695-706.

38 Jeavons PM, Harding GFA, Drasdo N, Furlong PLF, Bishop AI. Visual display units and epilepsy. Lancet 1985; ;:287.

39 Binnie CD, Kasteleijn-Nolst Trenite DGA, De Korte R, Wilkins A. Visual display units and risk of seizures. Lancet 1985;i:991.

40 North Carolina Occupational Safety and Health. Stress survey results. Durham NC: NCOSH, 1985.

41 Schnorr TM, Thun MJ, Halperin WE. Health hazard evaluation report At\&T, Southern Bell and United Telephone North Carolina. Cincinnatti OH: National Institute for Occupational Safety and Health, 1986. (HETA 85-452-1698.)

42 Johansson G, Aronsson G. Stress reactions in computerized administrative work. Journal of Occupational Behaviour 1984; 5:159-81.

43 Schleifer LM. An evaluation of mood disturbances and somatic discomfort under slow computer-response time and incentivepay conditions. In: Knave B, Widebäck PG, eds. Work with display units 86. Amsterdam: Elsevier, 1987:793-802.

44 Waern Y, Rollenhagen C. Reading text from visual display units (VDUs). International Journal of Man-Machine Studies 1983; 18:441-65.

45 Galitz WO. Screen design. In: Grandjean E, ed. Ergonomics and health in modern offices. London: Taylor \& Francis, 1984:400-4.

$46 \mathrm{Kessel} \mathrm{KL}$. Task analysis in applying software design principles. In: Grandjean E, ed. Ergonomics and health in modern offices. London: Taylor \& Francis, 1984:170-4.

47 Westlander G. How to identify organizational factors crucial to VDU-health. In: Knave B, Widebäck PG, eds. Work with display units 86. Amsterdam: Elsevier, 1987:565-77.

48 Floru R, Cail F. Data entry task on VDU: Underload or overload? In: Knave B, Widebäck PG, eds. Work with display units 86 . Amsterdam: Elsevier, 1987:756-67.

49 Johansson G. Growth and challenge vs wear and tear of humans in computer mediated work. In: Knave B, Widebäck PG, eds. Work with display units 86. Amsterdam: Elsevier, 1987:725-31.

50 House of Lords Select Committee on the European Communities. Visual display units. London: HMSO, 1988. (HL paper 110.)

\section{Correspondence and editorials}

The British Journal of Industrial Medicine welcomes correspondence relating to any of the material appearing in the journal. Results from preliminary or small scale studies may also be published in the correspondence column if this seems appropriate. Letters should be not more than 500 words in length and contain a minimum of references. Tables and figures should be kept to an absolute minimum. Letters are accepted on the understanding that they may be subject to editorial revision and shortening.

The journal now also publishes editorials which are normally specially commissioned. The Editor welcomes suggestions regarding suitable topics; those wishing to submit an editorial, however, should do so only after discussion with the Editor. 